\title{
Aurangzeb's Policies and the Decline of the Mughal Empire
}

In the February 1976 issue, Professor M. N. Pearson attempred an analysis of the determinants in the decline of the Mughal Empire. ${ }^{1}$ He attributes the empire's crisis to two principal factors: (I) the poor and unsatisfactory performance of almost all the powerful Mughal nobles; (2) Aurangzeb's move south in I68I-82. Though one may join issue with Professor Pearson in several matters, I shall limit myself here to the two most crucial points noted above.

Whereas the decadent character of Aurangzeb's umerah is generally accepted, Pearson does not seem to have taken into account the fact that, of his approximately I 4,500 mansabdars in 1695 , at least 8,000 existing in 1647 were, together with the crown, received by Aurangzeb as a legacy of the House in 1658 . By about the middle of Emperor Akbar's reign (1556-1605), the Mughal mansabdars had succeeded in arrogating to themselves the right of decision-making on vital issues of the empire. In the nineteenth regnal year, Akbar replaced land assignment with cash salaries to imperial officers, ${ }^{2}$ but such was the pressure from his nobles that, within a few years, he restored status quo ante. ${ }^{3}$ The imperial mansabdars, already enjoying almost all the military and executive powers in the realm, were henceforth in addition enabled to acquire more or less complete rights over the land revenue of the non-kbalisa areas-a circumstance that over the decades rendered the mansabdar community virtually supreme in the empire. It is well known that Emperors Jahangir ( $1605-27$ ) and Shah Jahan ( $1627-58$ ), leaning heavily on the mansabdars, had elevated and expanded their ranks. Aurangzeb's maintaining and further expanding the community was merely to honor the dynasty's commitment to them. Pearson would perhaps have done better if he had criticized Aurangzeb for so stubbornly and unimaginatively hanging on to the tradition, since the approximately 7,000 new mansabdars he enlisted over the last five decades were no improvement upon the older set of umerah.

Pearson puts Aurangzeb in the dock once again when he contends that what sounded the death knell of the Great Mughals was the emergence of Shivaji and his Marhattas as a parallel powerful body. Worse still, while Aurangzeb generally blundered in his dealings with the Marhattas, on four specific occasions-according to Pearson's assessment-his unwise and tactless handling of the rebels was decisive: in I657, when, as subedar of the Deccan, he failed to avail himself of the opportunity of crushing Shivaji, who had not yet grown too powerful; in I659, when Shaista Khan's debacle occurred; in 1664 , when Shivaji sacked Surat with impunity; and finally in r666, when the arch-rebel was presented to the Emperor at Agra. Shivaji and his band of followers were undoubtedly a formidable force in the later half of the seventeenth century, and the fact remains that Aurangzeb and his nobles failed to suppress them. It may also be conceded that Marhattas-by their perseverance, audacity, and vigor-had largely contributed to the general weakening of the empire and to the erosion of imperial prestige, time, and energy. But Marhattas as a body did

1 "Shivaji and the Decline of the Mughal Empire," JAS, XXXV, pp. $22 \mathrm{I}-35$.

${ }^{2}$ Abul Fazl, Akbarnama (Persian ed.), III (Calcutta, I 886), p. 117.
${ }^{3}$ Fazl, pp. 292, 327; Badayuni, Muntakbebat-utTawarikb, II, trans. by Ranking and Lowe (Patna, 1973), pp. I 88, I93, 2 I 8. 
not exist when Akbar died; they arose and grew over the subsequent decades. Their principal asset was their large and ever-growing strength of followers. Aurangzeb, however, did not ascertain the causes of the swelling of the Marhatta ranks, nor did he check the outflow of men from the imperial domains into Marhatta arms. Instead, Aurangzeb embarked upon a twenty-five-year-long campaign to reduce the insurgents. In other words, Aurangzeb omitted to trace the cause of the trouble, and confined himself to dealing with the resultant phenomenon of Shivaji and Marhatta power. Substantially following Aurangzeb, Pearson too concentrates almost exclusively on Aurangzeb vis-à-vis the Marhattas, disregarding the facts of the origin, character, composition, and circumstances attending the rise of Marhatta power. Large migrations of able-bodied men from their settled trade and base are usually prompted by political insecurity, social barriers, or economic crises; and it would seem that Marhattas (as well as the Sikhs, Jats, or Bundelas) were in fact the result of some unfortunate developments in the preceding decades within the imperial dominion occasioning large movements into rebel camps. Even the fact that, as the imperial arms made their halting progress in victories, it only added to the size and strength of the Marhattas, did not make either Aurangzeb or Pearson think twice before committing themselves any further. Each yard of land gained by Aurangzeb drove at least one individual to find refuge and perhaps livelihood with the Marhattas.

As a matter of fact, in medieval times, social and economic changes were very slow indeed: the rebel forces that crystallized during Aurangzeb's reign could not (and actually did not) emerge at one stroke in 1658 . The origin and beginnings of the Marhattas, Sikhs, Jats, and Bundelas can, with the help of available sources, be traced back to Jahangir or early years of Shah Jahan's reign; Aurangzeb merely reaped what his father and grandfather had sown. He certainly stumbled and blundered when faced with the predicament, but it is less than fair to hold him responsible for the sins of his royal progenitors.

Finally, societies, including that of the Great Mughals, are complex in character. To ascribe the 1707 catastrophe, and all that followed in its train, to a single causeespecially in the absence of a whirlwind invasion of a Taimur or a Nadir Shah-is an oversimplification. A Marhatta, Sikh, or Jat rebellion may weaken an empire or even reduce its territory, but in order to see the qualitative changes that came over the shape and interests of the empire, the threads of a denouement as complex as that of I 707 have to be sought very much earlier.

Jamia Millia Islamia, Delbi

HAMIDA KHATOON NAQVI 